\title{
A study on loess-derived colluvia in southern Limbourg (the Netherlands)
}

\author{
A. J. J. Bolt, H. J. Mücher, J. Sevink and J. M. Verstraten \\ Laboratory of Physical Geography and Soil Science, University of Amsterdam, \\ Dapperstraat 115, 1093 BS Amsterdam, the Netherlands
}

Accepted: 2 January 1980

Key words: colluvium, loess, micromorphology, quaternary

\section{Summary}

Most plateaus and relatively gentle slopes of the dissected terrace landscape of southern Limbourg are covered by loess, while Senonian chalk crops out on the mainly south facing steep slopes. The characteristic well-drained soil in loess is a Chromic Luvisol (Dutch classification: Radebrikgrond), which on the slopes is more or less truncated (Bergbrikgrond). On the footslopes and in the mostly dry valleys loess-derived colluvia occur.

A small loess area was selected for a more detailed study of the colluvia. Detailed morphometric and soil maps were prepared and two catenas studied in detail. Based on their macro- and micromorphological characteristics, two types of anthropogenic colluvium could be distinguished: a 'recent' colluvium, concentrated in the valleys without argilluviation and with Eutric Fluvisols (Dutch classification: Hofeerdgrond) and an 'old' colluvium, on the footslopes and in the valleys, with illuviation features - matriargillans and organoferriargillans and with Eutric Cambisols (Dutch classification: Hofeerdgrond).

On the plateaus and upper slopes geogenetic slope deposits mainly derived from loess were observed to occur. In these Chromic Luvisols similar to those in loess have been developed.

The colluvia were most probably formed through splash erosion; in the valleys combined with transport and accumulation of soil material through overland flow. The formation of the 'recent' colluvium results from a rather sudden sharp increase in colluviation.

\section{Introduction}

In the Netherlands little detailed study has been made of colluvial deposits, in particular those derived from loess. Previous field investigations in southern Limbourg, carried out by the present authors, suggested the occurrence of two 
types of loess-derived anthropogenic colluvia in southern Limbourg: an 'old' colluvium with weak illuviation features and with Cambisols in the valley and on the footslopes, and a 'recent' colluvium with Fluvisols in the valleys.

An area in which these two types of colluvium are well represented, was selected and studied in detail with respect to the composition, distribution and genesis of these colluvia.

The term colluvium, in this paper, is used for non-consolidated slope deposits, composed of macroscopically unstratified unsorted or poorly sorted heterogeneous material, containing coarse, mostly angular fragments of rocks and materials present on the overlying slope. It is thus used in the wider sense of the word, in analogy with many other investigators (Fairbridge, 1968; Gary et al., 1972; Kwaad \& Mücher, 1979). The term anthropogenic colluvium is used for colluvia containing anthropogenic materials and is more or less equivalent to the Dutch term 'Kolluvium'.

This study is not focussed on the role of factors such as biological activity (Imeson, 1976; Imeson \& Kwaad, 1976) and angle and length of slope (Kierkels, 1971), but on the characteristics of colluvia and their geogenesis.

\section{General information}

The area studied lies about $1 \mathrm{~km}$ east of Wijlre, in the plateau landscape of southern Limbourg (see Fig. 1). It is situated on the gentle north-facing slope of a large dry valley, which prior to the Late Quaternary had already acquired its present shape and depth of incision. The overlying plateau forms part of one of the older - Early Pleistocene - Maas terraces, probably the NoorbeekSimpelveld level (Brueren, 1945).

The subsoil of the plateau consists of Senonian chalk covered by chalk weathering residuum, the so-called 'clay with flints' (Dutch: Kleefaarde). For a study of its genesis and characteristics reference is made to Sevink \& Verstraten (1979), and Verstraten \& Sevink (1979a,b). During the Weichselian but also during earlier glacials, loess was deposited on the slopes and plateaus. Previous detailed soil surveys showed that older loess deposits are rare due to intense later erosion and denudation. The Weichselian loess however still covers most gentle slopes and plateaus.

It should be mentioned that Slager et al. (1978) consider the non-calcareous upper part of the youngest loess to be a separate deposit of Late Glacial post-Bølling — age, which was carbonate-free from the beginning. Evidence for their dating is not presented, nor is convincing evidence presented for the primary absence of carbonates in the loess. We therefore stick to the concept held by all other workers (for example Bouma et al., 1968; van den Broek, 1966; Diemont \& van de Westeringh, 1978; Kuyl, 1975; Mücher, 1973; Poelman, 1970) of one, youngest, calcareous loess which has been partly decalcified after its deposition.

Most authors (Reuter, 1964; Smolíková \& Lozek, 1973; de Bakker \& Schelling, 1966; and others mentioned above) agree that the characteristic soil of the loess, 


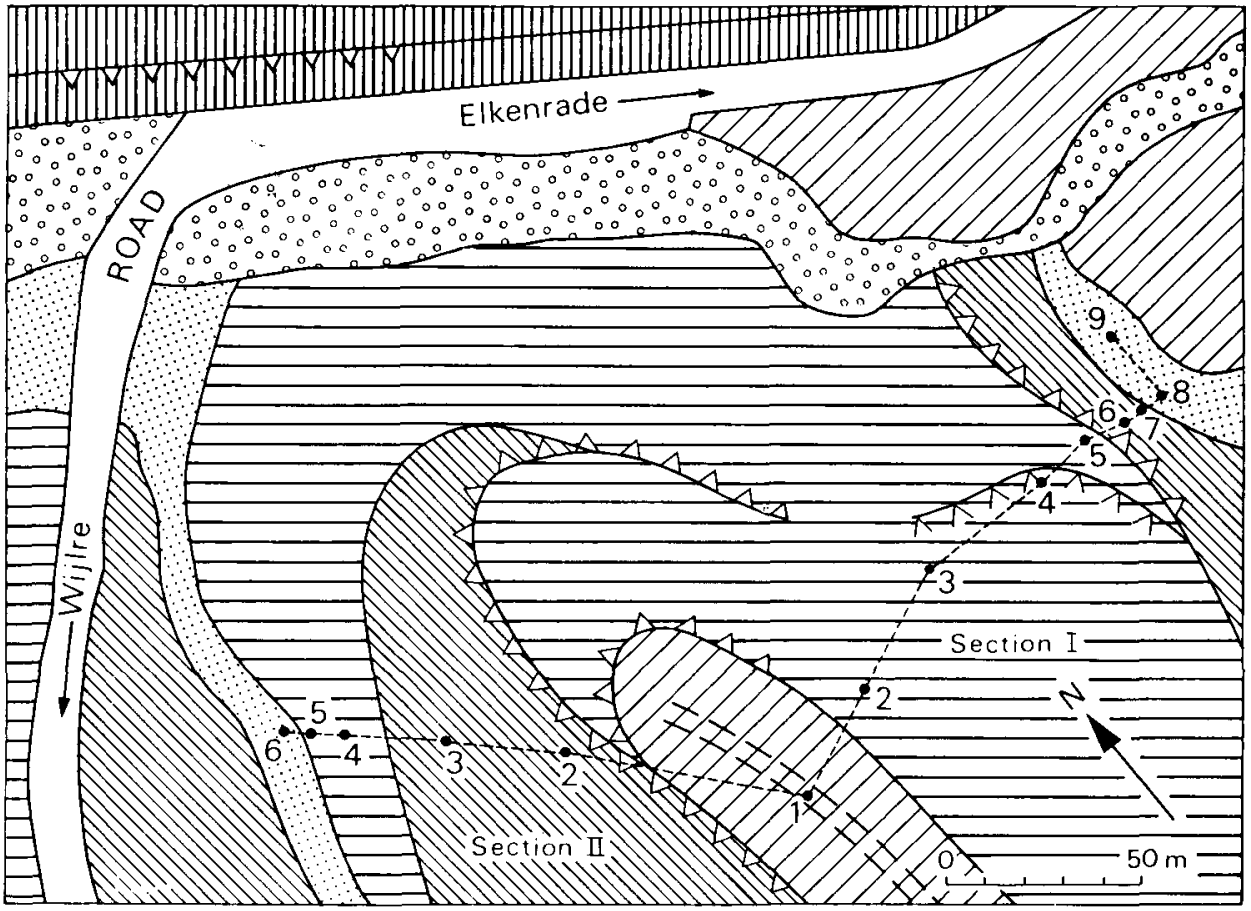

-3 profile number break of slope: $\triangle \triangle$ convex $y$ concave =ニ watershed

slope classes:
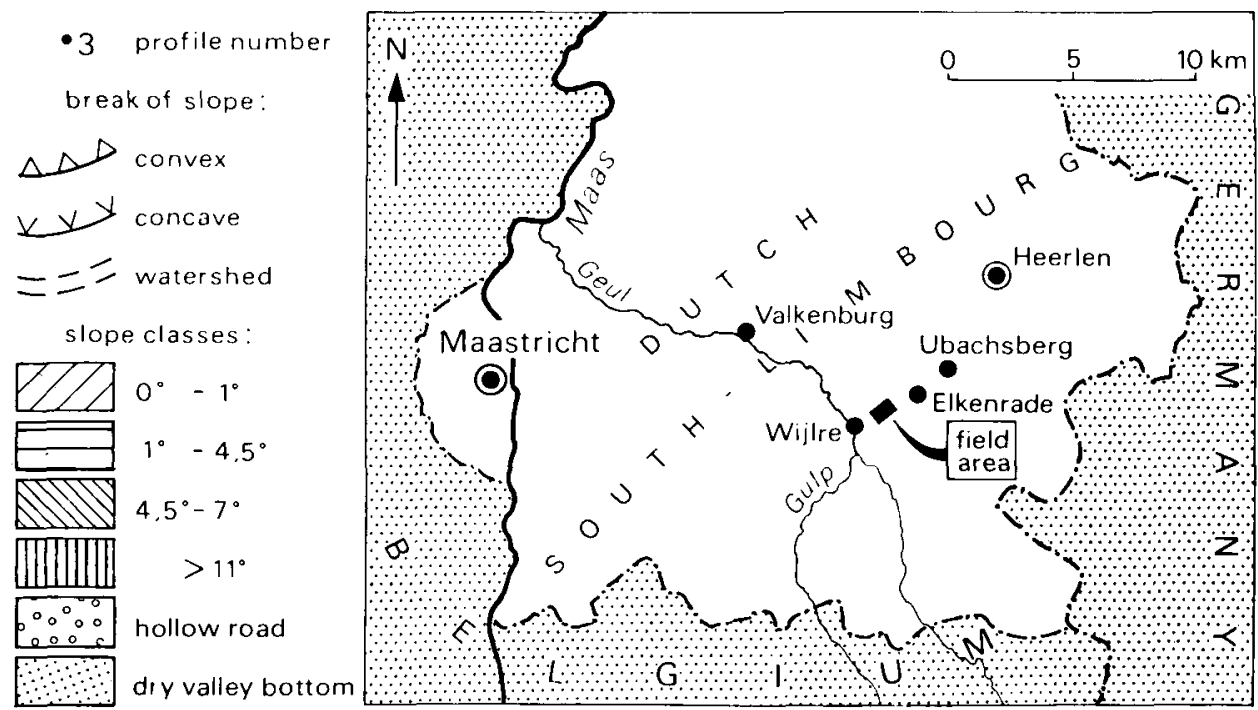

Fig. 1. Morphometric map of the investigated area with the legend and the location of the area. 
a Chromic Luvisol (Dutch classification: Radebrikgrond), was formed during the Atlantic or Subboreal. Pedological, archeological and palynological research showed that this process of argilluviation stopped, not as a result of climatic changes but of human activities (van den Broek, 1958/59; Bouma et al., 1968; Kwaad \& Mücher, 1977). Large-scale forest clearance occurred in particular in Roman times and the Early Middle Ages (Kuyl, 1978). These practices led to the erosion of all but the gentlest slopes $\left(<2^{\circ}\right)$ and to the accumulation of loess-derived colluvia, containing anthropogenic material on the footslopes and in the valleys. These valleys are virtually all dry, due to the high permeability of the chalk and the low water-table. Only after torrential rain do the dry valley bottoms contain running water for a short period of time.

\section{Methods}

The soils were surveyed by means of augering, in some cases to depths up to $6 \mathrm{~m}$, and in profile pits. The latter were also used for description and sampling. Soil profiles were described according to the FAO Guidelines for Soil Profile Description (FAO, 1968), while for the description of their colours use was made of the Munsell Soil Color Charts (Anon., 1954). The soils were classified according to the Legend of the Soil Map of the World (FAO, 1974) and to the Dutch system( de Bakker \& Schelling, 1966). For the classification of soils with buried horizons, the criteria mentioned in the Soil Taxonomy (Soil Survey Staff, 1975) have been used.

The analyses from the disturbed soil samples included grain size distribution and organic carbon content. The grain size distribution of material smaller than $2 \mathrm{~mm}$ was carried out by sedimentation and sieving following $\mathrm{H}_{2} \mathrm{O}_{2}$ and $\mathrm{HCl}$ pretreatment and dispersion with $\mathrm{Na}_{4} \mathrm{P}_{2} \mathrm{O}_{7}$.

Thin sections of the undisturbed soil samples were prepared according to the method of Jongerius \& Heintzberger (1975). For the description and interpretation of thin sections the terminology of Brewer (1976) was used, supplemented with terms introduced by Barratt (1969), Jongerius (1970) and van Schuylenborgh et al. (1970).

For the morphometric survey slope angles were measured with an Abney level. A levelling instrument was used to measure the vertical distances between the various profile pits.

\section{Field observations}

During the survey a large number of soil horizons and materials could be distinguished by their specific composition and pedological characteristics. These are listed in Table 1.

As clearly illustrated by their composition (presence of coal, charcoal, brick and pottery) the horizons $\mathrm{C}$ and IIB consist of anthropogenic colluvium (see Figs. 2 and 3) without macroscopic lamination. The distinction between 'old' and 'recent' colluvium is based on differences in soil properties (darker colour, weaker 
Table 1. Macromorphological description of idealized profile.

\begin{tabular}{ll}
\hline Material & $\begin{array}{l}\text { Horizon }+ \\
\text { maximum thickness }\end{array}$
\end{tabular}

Plough layer Ap, up to $50 \mathrm{~cm}$

Very dark grayish brown to very dark brown (10YR $3 / 2-2 / 2$ ) silt loam; moderate angular to subangular blocky; friable to firm; fragments of coal, charcoal, brickstone and pottery; abrupt smooth boundary

'Recent' loess- C, up to $100 \mathrm{~cm}$ derived colluvium

Yellowish brown (10YR 5/6) silt loam; fine prominent strong brown (7.5YR 5/6) mottles; massive to weak medium angular blocky; friable; medium and very fine pores; fragments of slate, chert, coal, charcoal and brickstone; small strong brown (7.5YR 5/6) soft rounded ferric nodules; clear to gradual smooth boundary

'Old' loess-derived IIB, $110 \mathrm{~cm}$ colluvium

Yellowish brown (10YR 5/4) silt loam; fine light yellowish brown (10YR 6/4) mottles with sharp and distinct boundaries; weak medium angular blocky; very friable; pores with dark dirty yellowish brown (10YR 5/4) cutans on the walls; very fine to medium pores; locally weathered chalk; very small strong brown (7.5YR 5/6) soft rounded ferric nodules; fragments of coal, charcoal and brickstone; worm excrements; abrupt smooth boundary

Youngest loess including Upper Weichselian loessderived slope deposit
IIIB2t, $65 \mathrm{~cm}$

LIIB3t, $160 \mathrm{~cm}$

IIIC1, $380 \mathrm{~cm}$

IIIC2, $235 \mathrm{~cm}$

Middle loess

IVC, > $260 \mathrm{~cm}$

Geogenetic slope VC, $50 \mathrm{~cm}$ deposit
Brown to strong brown (7.5YR 5/5) silt loam; strong to moderate very coarse to medium subangular blocky; firm; patchy strong brown (7.5YR 5/6) and brown to dark brown (7.5YR 4/2) broken moderate thick to thick cutans; gradual wavy boundary

Yellowish brown (10YR 5/6) silt loam; moderate subangular blocky decreasing with depth to medium subangular blocky; firm decreasing with depth to friable; patchy strong brown (7.5YR 5/6) thin to thick cutans on broad ped faces; gradual wavy boundary

Yellowish brown (10YR 5/6) silt loam; non-calcareous; massive; very friable; abrupt smooth boundary

Brownish yellow (10YR 6/6) silt loam; calcareous; massive; very friable; at the base of this horizon occasionally a thin $(10 \mathrm{~cm}$ thick) gravel layer with angular to subangular chert and rounded quartz gravel; clear to gradual wavy boundary

Yellowish brown to dark yellowish brown (10YR 5/44/4) silt loam; non calcareous; massive, locally laminated; very friable; with very thin $\mathrm{Fe} / \mathrm{Mn}$ layers; abrupt smooth boundary

Yellowish brown (10YR 5/8 silty clay loam; mixture of loess, clay with flints and chalk; massive; firm; clear wavy boundary 
Table 1. (continued).

\begin{tabular}{lll}
\hline Material & $\begin{array}{l}\text { Horizon }+ \\
\text { maximum thickness }\end{array}$ & Description \\
Clay with flints & VIC, $40 \mathrm{~cm}$ & $\begin{array}{l}\text { Yellowish brown (10YR 5/8) clay to clay loam with } \\
\text { light olive brown }(2.5 \mathrm{Y} 5 / 4) \text { mottles; massive; sticky } \\
\text { to very sticky; clear smooth boundary }\end{array}$ \\
$\begin{array}{l}\text { Weathered chalk }+ \text { clay with flints } \\
\text { VIC, }+\mathrm{R}, 80 \mathrm{~cm}\end{array}$ & $\begin{array}{l}\text { Light yellowish brown (2.5Y 6/4) slightly gravelly } \\
\text { clay loam; changing with depth to weathered chalk } \\
\text { with hard gravel sized fresh chalk fragments; massive; } \\
\text { slightly sticky decreasing with depth to friable; abrupt } \\
\text { smooth boundary }\end{array}$ \\
Chalk & VIR, $>300 \mathrm{~cm}$ & Light gray (2.5Y 7/2) chalk (Senonian) \\
\hline
\end{tabular}

structure and absence of cutans in 'recent' colluvium) and their position in the profile (see Fig. 3).

The horizons with the prefix III are in Upper Pleniglacial loess and loessderived slope deposits; together they form the eroded Chromic Luvisols characteristic for the loess on more elevated parts of southern Limbourg. Horizon IVC consists of older non-calcareous loess, most probably the middle loess, while horizon $\mathrm{V}$ is a mixture of loess-derived material and of chalk and its weathering residue. Its properties range from silt loam with gravel-sized chalk fragments to silty clay loam, free of any gravel. Horizons VI basically represent stages in the weathering of chalk.

In Fig. 2 a map is presented showing the distribution and nature of the various soil types. Their classification is based on field observations and analyses. The major part of the area is covered by truncated Chromic Luvisols, developed in loess. Comparison with Fig. 1 shows that these truncated soils are restricted to watersheds and slopes with an angle of less than $7^{\circ}$.

The Eutric Cambisols (Dutch classification: Hofeerdgrond), developed in 'old' loess-derived colluvium, mainly occur on the footslopes and in the valleys. Eutric Fluvisols (Dutch classification: Hofeerdgrond), developed in 'recent' loess-derived colluvium, are largely restricted to the dry valleys. Calcaric Regosols (Dutch classification: Ooivaaggrond or Krijteerdgrond) dominate the upper part of the steep $\left(>11^{\circ}\right)$ slopes in chalk, whereas their lower part and the footslopes (angles between $0^{\circ}$ and $12^{\circ}$ ) are dominated by Calcic Cambisols (Dutch classification: Hofeerdgrond) and Calcaric Fluvisols (Dutch classification: Hofeerdgrond), both in colluvium. This colluvium is largely derived from chalk and its weathering products and therefore will not be considered in the following discussion. Most Dutch soil scientists prefer to classify the colluvial soils as 'Ooivaaggronden'. However strict application of the criteria enforces a classification as 'Hofeerdgronden'.

The cross sections (see Fig. 2) resembled each other strongly with respect to the spatial distribution and other characteristics of the various horizons and therefore only the cross section of Catena I (see Fig. 3) is presented. It shows 


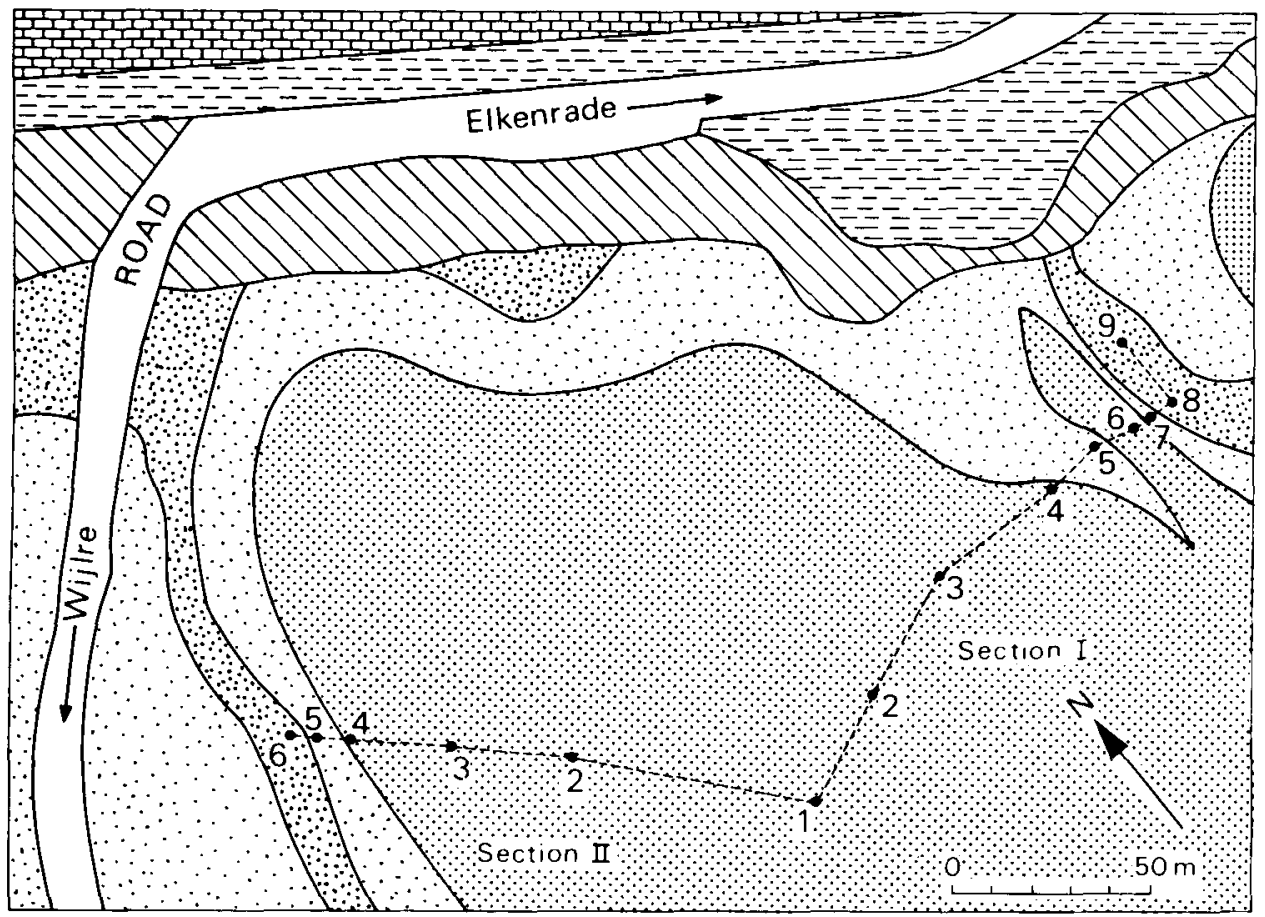

calcaric regosols in chalk

$=\overline{-E}$

calcic cambisols/calcaric fluvisols in colluvium, mainly derived from chalk

truncated chromic luvisols in loess (in situ)

eutric cambisols in "old" loess-derived colluvium

$\because$ eutric fluvisols in "recent" loess-derived colluvium

DD reworked (anthropogenic) deposits

Fig. 2. Soil map of the investigated area based on macroscopic observations with the legend

that the calcareous loess thins out and disappears towards the dry valley, a pattern repeated by the non-calcareous loess. The distribution of 'old' and 'recent' loessic colluvium is furthermore clearly illustrated.

\section{Results}

In order to reduce the number of analytical data available, most results (with a 


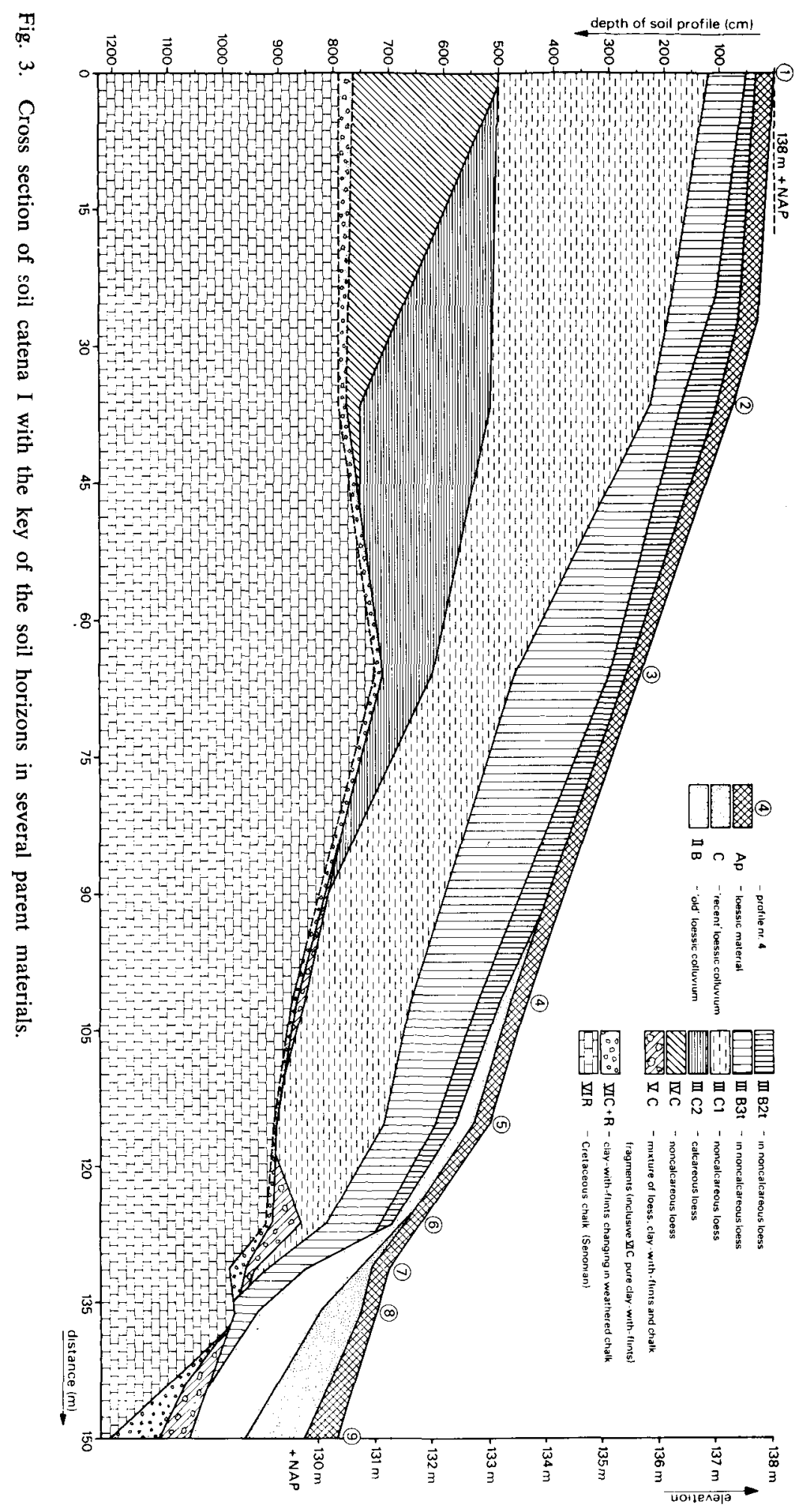


small range) have been combined into average values or characteristics of the various horizons distinguished. In Fig. 4 their average grain-size distribution, lime content and organic carbon content are indicated.

In Fig. 5 more specific data are presented: the fractions $<2,2-16,16-50$ and $>75 \mu \mathrm{m}$ and the organic carbon content.

The micromorphological descriptions presented in Table 2 are based on study of samples of several soils.

\section{Discussion}

\section{General}

Although the research was centered on the colluvia, some observations were made on the older deposits. These will be discussed first.

The cross section illustrates that horizons composed of weathered chalk and/or clay with flints are of very limited thickness. Comparison with the plateaus, where these horizons are much thicker developed (see Sevink \& Verstraten, 1979), leads to the conclusion that the area under discussion has been rather severely eroded and denudated prior to the loess deposition. Horizon VC consists of an unstratified chaotic mixture of various amounts of loess, clay with flints, and chalk fragments and is thickest on the footslope and in the valley. Considering its characteristics it was most probably formed by mass movements and not by running water.

The lower non-calcareous loess (IVC) was only observed in two deeper borings. The position and characteristics observed (burial by calcareous loess, laminated, slightly darker colour) suggest that this is the middle loess, probably with remnants of the Kesselt soil (see Kuyl, 1975).

The horizons with the prefix III are all in the youngest Upper-Pleniglacial loess and represent horizons in different stages of weathering and soil formation. Field observations showed that the loess contains some gravel. This, combined with the increase of the fraction $>75 \mu \mathrm{m}$ and the decrease of the fraction 16-50 $\mu \mathrm{m}$ indicates that part of the loess has been transported downslope after its eolian

\begin{tabular}{|c|c|c|c|c|c|c|c|c|c|c|c|}
\hline \multicolumn{2}{|c|}{ section I } & \multirow{2}{*}{\multicolumn{2}{|c|}{$\begin{array}{l}\text { weight \% } \\
\text { of total } \\
\text { soil }\end{array}$}} & \multicolumn{8}{|c|}{$\begin{array}{c}\text { gram sıze distribution } \\
\text { (weight } \% \text { mineral fraction) }\end{array}$} \\
\hline \multirow{2}{*}{$\begin{array}{c}\text { soll } \\
\text { horizon }\end{array}$} & \multirow{2}{*}{$\begin{array}{l}\text { depth } \\
\text { in } \mathrm{cm}\end{array}$} & & & & & & & & & & \\
\hline & & $\operatorname{org} C$ & $\mathrm{CaCO}_{3}$ & 2 & & & & & & & \\
\hline$A p$ & $20-30$ & 1.6 & - & 1.6 & 2.0 & 38.5 & 26.0 & 9.5 & 3.0 & 1.5 & 18.0 \\
\hline $\mathrm{C}$ & $30-40$ & 0.4 & - & 1.4 & 3.0 & 38.0 & 30.5 & 9.5 & 3.0 & 1.0 & 14.0 \\
\hline II $\mathrm{B}$ & $130-145$ & 0.7 & - & 3.6 & 3.5 & 31.0 & 32.0 & 10.0 & 3.0 & 2.0 & 14.5 \\
\hline III $B 2 t$ & $80 \cdot 90$ & 0.4 & - & 0.7 & 2.0 & 30.0 & 28.5 & 11.0 & 4.0 & 2.0 & 21.5 \\
\hline III B3t & $130-140$ & 01 & - & 1.3 & 2.5 & 355 & 34.5 & 5.5 & 2.5 & 1.5 & 16.5 \\
\hline III $\mathrm{C} 1$ & $90-110$ & - & - & 2.2 & 4.5 & 28.0 & 31.5 & 12.5 & 3.5 & 1.5 & 16.5 \\
\hline II $\mathrm{C} 2$ & $225-240$ & - & 24.1 & 2.0 & 5.0 & 48.0 & 23.5 & 6.0 & 2.5 & 1.0 & 12.0 \\
\hline EZ C & $680-690$ & 0.3 & - & 4.4 & 2.0 & 18.5 & 28.5 & 13.0 & 6.5 & 3.0 & 24.0 \\
\hline
\end{tabular}

Fig. 4. General characteristics of the loess deposits and of the loess-derived materials at various depths of section $I$. 


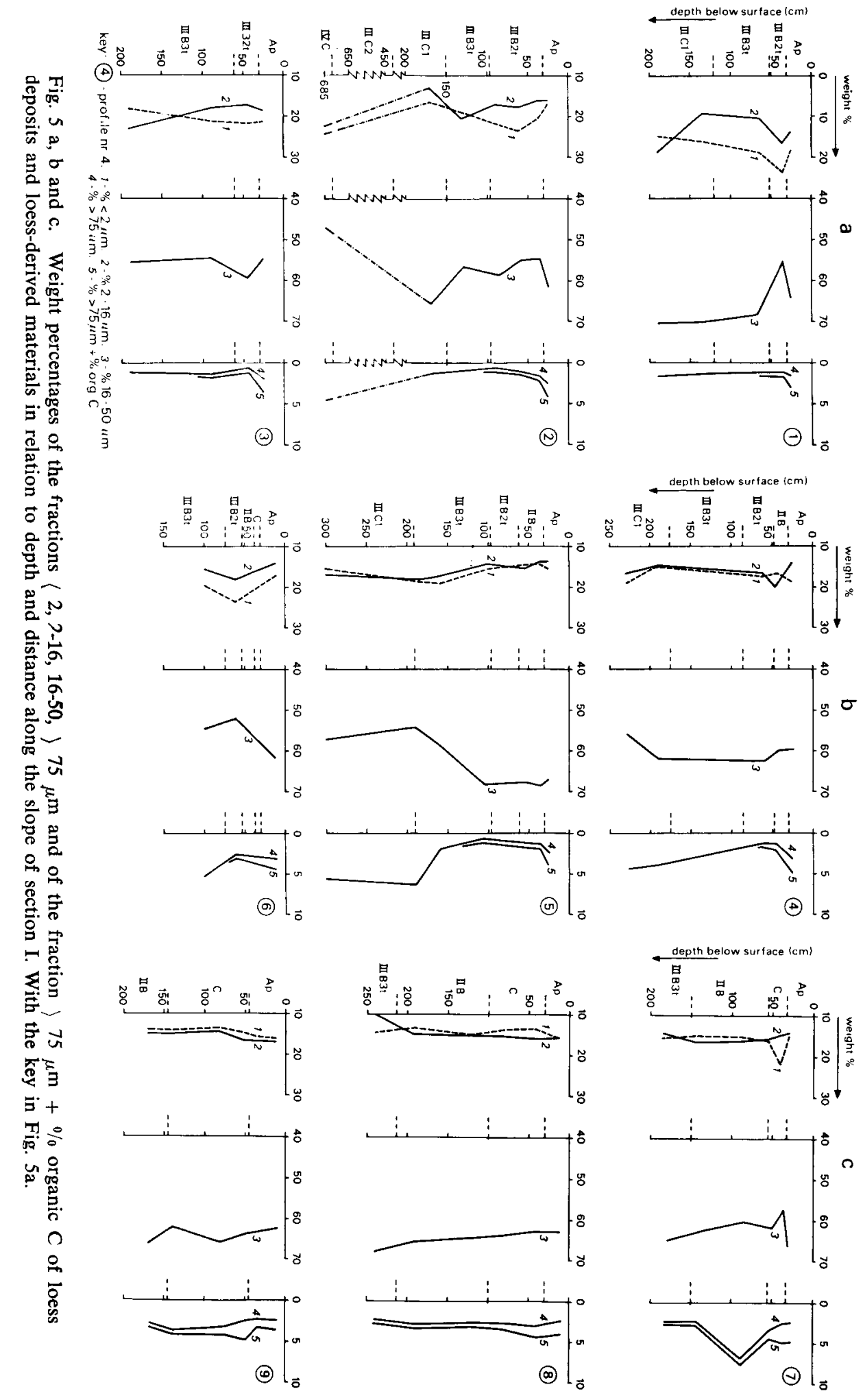




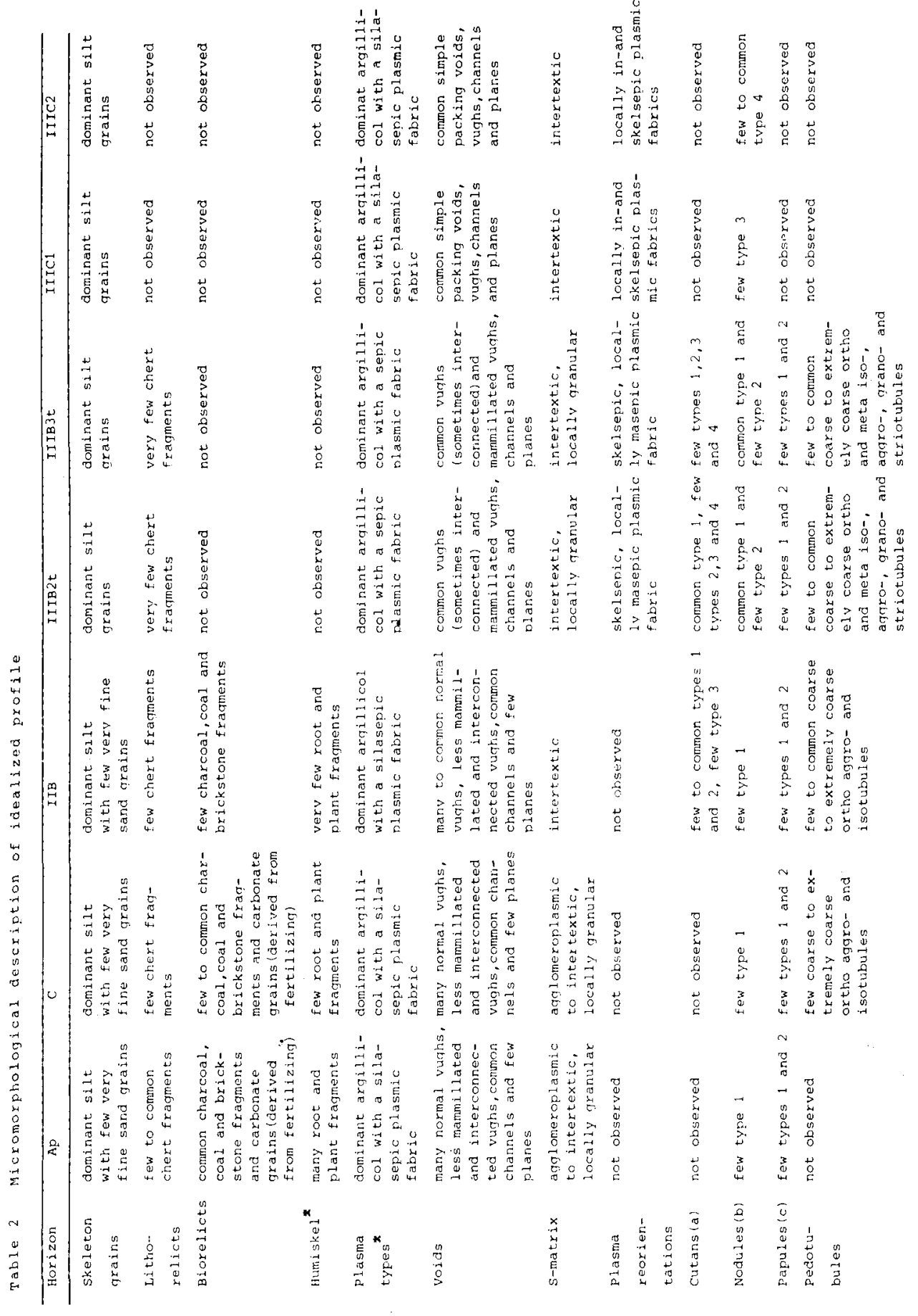




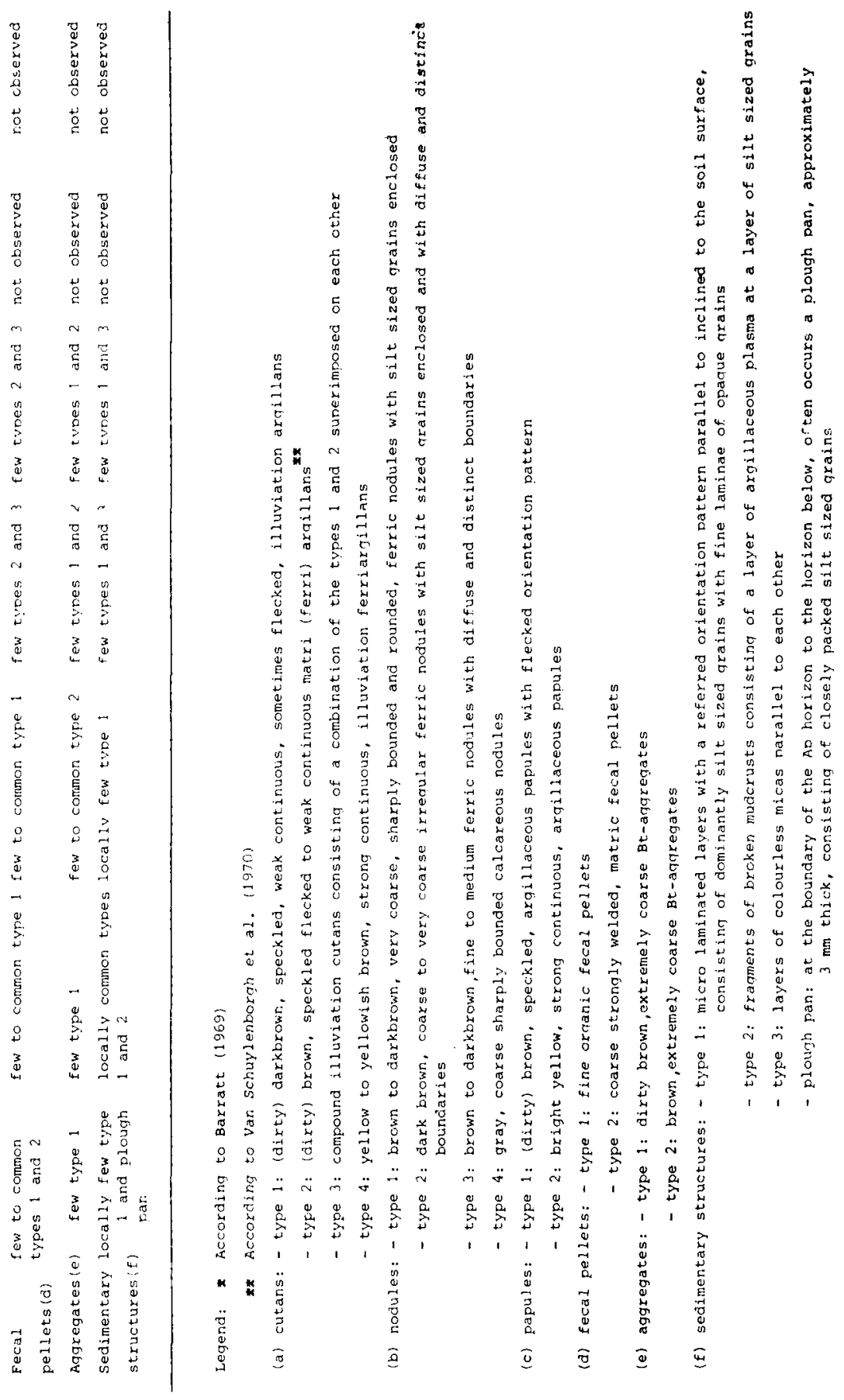


deposition, and thus represents a Late Weichselian slope deposit of geogenetic origin (see also Mücher, 1974).

The Chromic Luvisol in the youngest loess has been severely eroded, in particular on the footslope and in the valley, as indicated by the cross-section. This can also be inferred from the grain size analyses in Fig. 5, where it can be seen that A2 horizons are lacking and that the B2t horizon has been partly eroded.

\section{The colluvia}

In the area studied the following processes may have contributed to the formation of loess-derived colluvia:

- transport by overland flow, either during rainfall (rainwash) or after precipitation (afterflow and melt-water flow). These mechanisms always give rise to laminated deposits (Mücher \& de Ploey, 1977).

- movement of soil material by raindrop impact, including splash creep (Moeyersons \& de Ploey, 1976; Kwaad, 1977; Mücher \& de Ploey, 1977). These processes result in unstratified deposits.

- transport by frost creep and other forms of soil creep.

- transport of soil material as a direct effect of ploughing.

No evidence has been found to suggest that solifluction or other forms of mass movements were active during historic times in the loess areas of NW Europe. Furthermore no observations were made regarding the transporting effect of ploughing. The colluvia observed are mainly unstratified. Those on the valley slopes show no stratification at all, while the colluvia in the valley bottoms sometimes appear under the microscope, to be weakly laminated. The hypothesis that originally present strong lamination and good sorting of the individual particles in the colluvia would have disappeared completely (even at microscopical scale) owing to biological activity, is tenuous. In such a case both loessic colluvia would have been reworked into excrements and also a new random distribution pattern would have arisen. Evidence for such a strong biological activity was not found however. Although disturbance of the laminae by tillage, resulting in unstratified deposits, cannot be completely excluded, its effect is, to the authors' opinion, most probably limited to the obliteration of macroscopic lamination. Lastly, there is no reason to assume that the disturbance of originally existing lamination through biological homogenization or tillage was more intense on the lower valley slope than on the valley bottom.

It is therefore concluded that splash erosion, including splash creep has been the dominant process in the formation of the colluvia. Near and on the valley bottom however transport by overland flow also played a role, with deposition during rainwash, afterflow or melt-water flow (see also Mücher et al., 1980).

The distinction between the two types of colluvium with respect to their age as based on macroscopic criteria, is supported by the microscopic observations (Table 2). These showed that in the 'old' colluvium three types of illuviation cutans occur, while in 'recent' colluvium cutans are lacking.

Four types of illuviation cutans could be recognized: 
- type 1: (dirty) darkbrown, speckled, weak continuous, sometimes flecked, ferriargillans;

- type 2: (dirty) brown, speckled, flecked to weak continuous, matriargillans (van Schuylenborgh et al., 1970) or agricutans (Jongerius, 1970) consisting of clay, silt and organic matter;

- type 3: compound cutans consisting of a combination of the types 1 and 2;

- type 4: yellow to yellowish brown, strong continuous, ferriargillans.

The matriargillans (van Schuylenborgh et al., 1970) or agricutans (Jongerius, 1970 ) of type 2, composed of clay, silt and organic matter are the most characteristic features. Kwaad \& Mücher (1979), in accordance with other workers, concluded that matriargillans, matrans or agricutans result from a breakdown of structure of surface horizons due to cultivation.

The cutans of type 1 could be a type transitional between agricutans (= type 2 ) and ferriargillans ( $=$ type 4 ). Indications are:

- If occurring together with cutans of type 4, those of type 1 are observed closest to the remaining void.

- Cutans of type 1, elsewhere described as 'dark brown organoferriargillans' have been observed in a loess-derived slope deposit, which is free of anthropogenic material (Mücher, 1974) and therefore predates the 'old' colluvium. Therefore this deposit was considered to be a 'geogenetic slope deposit'.

The regular presence however of cutans of type 1 and of the compound cutans of type 3 in the 'old' colluvium proves, that they were laso formed in soils under cultivation. An explanation could be that they were formed during and directly after the clearing of the forest, but also at a later time. Cutans of type 1,2 and 3 were observed at considerable depths, i.e. even in IIIB3t horizons, in which they cover the cutans of type 4 . This explains the relatively high organic carbon content of these horizons (see Fig. 5).

The absence of agricutans in the 'recent' colluvium could be due to such a high rate of deposition that soil formation could not keep up with it.

The colluvial deposits appeared to be virtually free of pollen grains. Attempts to date similar colluvial deposits in the nearby valley of the Geul by means of pollen analyses have failed. The dating of the colluvial phases therefore encounters serious problems, however some evidence exists. In the first place the colluvia were most likely formed since the major periods of deforestation and reclamation, which according to Kuyl (1978) were the Roman period and the Early Middle Ages. This is in accordance with the results of a palynological study by Havinga \& van den Berg van Saparoea (1980). An earlier age in fact can be virtually excluded as 'old' colluvium abundantly contains anthropogenic materials, pointing to a rather intense and extensive agricultural land use which is very unlikely to have occurred in pre-Roman times.

Secondly the descriptions and analyses show that the transition from 'old' to 'recent' colluvium is rather abrupt and that these colluvia exhibit large differences in the degree of post-depositional soil formation. It can therefore be concluded that the 'recent' colluvium has formed as a result of a recent and sharp increase in erosion. This increase could be due to the introduction of modern mechanized 
agriculture in the last decades, with its emphasis on removal of 'graften' (slope breaks) and use of heavy machinery.

A tentative dating might thus be as follows: the formation of the 'old' colluvium started in the Roman period or the Early Middle Ages, and the 'recent' colluvium about 1900 A.D.

Field observations in the past ten years showed that colluviation and subsequent deposition of loess-derived materials locally causes serious damage to crops (for example through burial of seedlings, or partial removal of top soil).

This article intends to stimulate the study of erosion and sedimentation processes in the Dutch loess areas, in order to promote more adequate soil conservation.

\section{Acknowledgements}

The authors gratefully acknowledge the kind co-operation of the farmers in the region between the villages Wijlre and Ubachsberg. Especially we thank Ing. J. H. A. L.'Ortye; at his land we dominantly carried out the detailed mapping with many augerings and several profile pits.

We sincerely thank Dr A. C. Imeson and Drs F. J. P. M. Kwaad for critical reading of the manuscript and for highly stimulating discussions.

Thanks are due to Mr A. Eikeboom, Mr A. J. van Geel, Mrs G. J. M. Scholts, Mr L. de Lange, Dr A. Remmelzwaal and Mr C. Zeegers for the photographical work, making the drawings, typing the manuscript, physical and chemical analyses, assisting in the field, and for preparing the thin sections.

\section{References}

Anonymus, 1954. Munsell Soil Color Charts. Munsell Color Company, Baltimore, Md., USA. Bakker, H. de \& J. Schelling, 1966. Systeem van bodemclassificatie voor Nederland. De hogere niveaus. Pudoc, Wageningen, $217 \mathrm{pp}$.

Barratt, B. C., 1969. A revised classification of microscopic soil materials with particular reference to organic components. Geoderma 2: 257-272.

Bouma, J., L. J. Pons \& J. van Schuylenborgh, 1968. On soil genesis in temperate humid climate. VI. The formation of a glossudalf in loess (silt loam). Neth. J. agric. Sci. 16: 58-70.

Brewer, R., 1976. Fabric and mineral analysis of soils. R. E. Krieger, Huntington, New York, 482 pp.

Broek, J. M. M. van den, 1958/1959. Bodenkunde und Archäologie mit besonderer Bezugnahme auf die Ausgrabungen im Neolithikum von Sittard und Geleen. Palaeohistoria 6/7: 7-18.

Broek, J. M. M. van den, 1966. De bodem van Limburg. Toelichting bij blad 9 van de bodemkaart van Nederland, schaal 1: 200.000. Stiboka, Wageningen, 217 pp.

Brueren, J. W. R., 1945. Het terrassenlandschap van Zuid-Limburg. Meded. Geol. St., serie C-VI nr. 1, 93 pp. Ernest van Aelst, Maastricht.

Diemont, W. H. \& W. van de Westeringh, 1978. Graften in Zuid-Limburg: groen of kaal, levend of verdwijnend? Tijdschr. Kon. Ned. Heide Mij. 89 (3): 99-107.

FAO, 1968. Guidelines for soil profile description. Soil Survey and Fertility Branch, Land and Water Development Division, FAO, Rome, $53 \mathrm{pp}$.

FAO, 1974. FAO-UNESCO Soil Map of the World. Vol. 1. Legend. Unesco, Paris, 59 pp. 


\section{LOESS-DERIVED COLLUVIA IN SOUTHERN LIMBOURG}

Fairbridge, R. W. (Ed.), 1968. The encyclopedia of geomorphology. Reinhold, New York, $1295 \mathrm{pp}$.

Gary, M., R. McAfee \& C. L. Wolf (Ed.) 1972. Glossary of geology. American Geol. Institute, Washington, $805 \mathrm{pp}$.

Havinga, A. J. \& R. M, van den Berg van Saparoea, 1980. Former vegetation and sedimentation in the valley of the river Geul. In: W. van de Westeringh et al., (Ed.), Soil conditions, soli carbonates and former vegetation in the Geul valley from Gulpen to Meerssen (South Limburg, Netherlands). Meded. LandbHogesch., Wageningen 80-8: 47-58.

Imeson, A. C., 1976. Some effects of burrowing animals on slope processes in the Luxembourg Ardennes. 1. The excavation of animal mounds in experimental plots. Geogr. Ann. 58, A. 1-2: 115-125.

Imeson, A. C. \& F. J. P. M. Kwaad, 1976. Some effets of burrowing animals on slope processes in the Luxembourg Ardennes. 2. The erosion of animal mounds by splash under forest. Geogr. Ann. 58, A. 4: 317-328.

Jongerius, A., 1970. Some morphological aspects of regrouping phenomena in Dutch soils. Geoderma 4: 311-331.

Jongerius, A. \& G. Heintzberger, 1975. Methods in soil micromorphology. A technique for the preparation of large thin sections. Netherlands Soil Survey Institute, Wageningen, Netherlands. Soil Survey Papers 10, 48 pp.

Kierkels, M. H. H., 1971. Erosie en verkaveling in de ruilverkaveling 'Ransdalerveld'. Cultuurtech. Tijdschrift 11 (2): 78-84.

Kuyl, O. S., 1975. Löss. Grondboor en Hamer, 29 (1): 2-12.

Kuyl, O. S., 1978. Lösslandschap in Zuid-Limburg. In: G. J. van den Berg (Ed.), Luchtatlas van Nederland. Romen, Bussum, pp. 56-57.

Kwaad, F. J. P. M., 1977. Measurements of rainsplash erosion and the formation of colluvium beneath deciduous woodland in the Luxembourg Ardennes. Earth Surface Processes 2: 161-173.

Kwaad, F. J. P. M. \& H. J. Muicher, 1977. The evolution of soils and slope deposits in the Luxembourg Ardennes near Wiltz. Geoderma 17: 1-37.

Kwaad, F. J. P. M. \& H. J. Mücher, 1979. The formation and evolution of colluvium on arable land in northern Luxembourg. Geoderma 22 (3) 173-192.

Moeyersons, J. \& J. de Ploey, 1976. Quantitative data on splash erosion simulated on unvegetated slopes. Z. Geomorph. N.F. 25: 120-131.

Mücher, H. J., 1973. Enkele aspecten van de loess en zijn noordelijke begrenzing, in het bijzonder in Belgisch en Nederlands Limburg en in het daaraangrenzende gebied in Duitsland. Geogr. Tijdschr. (Kon, Ned. aardrijksk. Gen.) 7 (4): 259-276.

Mücher, H. J., 1974. Micromorphology of slope deposits: the necessity of a classification. In: G. K. Rutherford (Ed.), Soil microscopy. Proc. 4th Int. Working-Meeting Soil Micromorphol. Limestone Press, Kingston, Ontario, Canada, pp. 553-566.

Mücher, H. J. \& J. de Ploey, 1977. Experimental and micromorphological investigation of erosion and redeposition of loess by water. Earth Surface Processes 2: 117-124.

Mücher, H. J., J. de Ploey \& J. Savat, 1980. Response of loess materials to simulated translocation by water: micromorphological observations. Earth Surface Processes (in press).

Poelman, J. N. B., 1970. Erosie van lössgronden. Boor en Spade 17: 177-187.

Reuter, G., 1964. Mikromorphologie lessivierter Böden in verschiedenen Klimagebieten. In: A. Jongerius (Ed.), Soil micromorphology. Proc. 2nd Int. Working-Meeting Soil Micromorphol. Elsevier, Amsterdam, pp. 213-218.

Schuylenborgh, J. van, S. Slager \& A. G. Jongmans, 1970. On soil genesis in temperate humid climate. VIII. The formation of a 'Udalfic' Eutrochrept. Neth. J. agric. Sci. 18: $207-214$.

Sevink, J. \& J. M. Verstraten, 1979. Clay soils on limestone in South Limburg, the Netherlands. 1. Setting and general characteristics. Geoderma 21 (4): 251-267.

Slager, S., A. G. Jongmans, R. Miedema \& L. J. Pons, 1978. Fossil and recent soil formation in Late Pleistocene loess deposits in the southern part of the Netherlands. Neth. J. agric. Sci. 26: 326-335. 
Smolíková, L. \& V. Lózek, 1973. Der Bodenkomplex von Velky Hubenov als Beispiel einer retrograden Bodenentwicklung im Laufe der Nacheiszeit. Casopsis Mineral. Geol. 18: 365377.

Soil Survey Staff, 1975. Soil taxonomy. A basic system of soil classification for making and interpreting soil surveys. Agriculture Handbook No. 436, Soil Conservation Service, U.S. Department of Agriculture, Washington, D.C., 754 pp.

Verstraten, J. M. \& J. Sevink, 1979a. Clay soils on limestone in South Limburg, the Netherlands. 2. Weathering. Geoderma 21 (4): 269-280.

Verstraten, J. M. \& J. Sevink, 1979b. Clay soils on limestone in South Limburg, the Netherlands. 3. Soil formation. Geoderma 21 (4): 281-295. 